\title{
DO REVISITAR AO RECRIAR A HISTÓRIA NACIONAL: UMA POSSÍVEL LEITURA DE A SEGUNDA PÁTRIA, DE MIGUEL SANCHES NETO
}

\author{
Thiana Nunes Cella*
}

\begin{abstract}
RESUMO: O presente texto configura-se como uma análise do romance A Segunda Pátria (2015), do escritor e ensaísta paranaense Miguel Saches Neto. Por uma perspectiva comparatista, examina as relações entre o discurso histórico e o discurso literário, bem como as diferentes tipologias críticas de narrativas híbridas de história e ficção, e aproxima a referida obra literária ao denominado romance histórico contemporâneo de mediação, concebido por Fleck (2017). Atém-se, portanto, aos aspectos basilares dessa narrativa romanesca: a releitura crítica e verossímil do passado, realizada por meio de um foco narrativo excêntrico, que permite a apresentação de perspectivas antes marginalizadas, relegadas ao esquecimento. Dessa forma, mostra como a produção literária contemporânea se articula intimamente ao discurso histórico, problematiza sua representação e questiona as verdades da história hegemônica.
\end{abstract}

PALAVRAS-CHAVE: Ficção; História; Miguel Sanches Neto; Romance histórico contemporâneo de mediação.

\section{Introdução}

A produção literária híbrida de história e ficção contemporânea, principalmente produzida a partir da segunda metade do século XX, tem passado por um impasse: as teorias que, até agora, nortearam as análises e estudos sobre essa produção estão alicerçadas

\footnotetext{
* Doutoranda em Letras pelo Programa de Pós-Graduação em Letras da Universidade Estadual do Oeste do Paraná (Unioste). Mestra em Letras pelo Programa de Pós-Graduação da Universidade do Cento-Oeste do Paraná (Unicentro). Docente do Instituto Federal do Paraná (IFPF), Campus Coronel Vivida.
} 
nos pilares relacionados ao novo romance histórico latino-americano ou à metaficção historiográfica, as quais, por estarem alicerçadas ao experimentalismo linguísticos e estético e ao desconstrucionismo, já não representam plenamente a produção nacional, que passou a ter características menos radicais, com narrativa mais linear e menos "caótica" que as vertentes anteriores.

Suprindo a ausência de estudos sobre a produção mais recente de romances de extração histórica, a concepção de romance histórico contemporâneo de mediação (FLECK, 2017) se destaca. Este, é aqui tomado como uma possibilidade genuína de interpretação e análise das escritas híbridas de história e ficção produzidas, especialmente, após a década de 80. Essa modalidade romanesca, pertencente às escrituras híbridas de história e ficção, é aqui percebida como um vantajoso caminho para o questionamento da representação do passado, que ultrapassa os limites entre as categorias da história e da ficção, busca a reavaliação do discurso oficial, bem como da composição estético formal do romance tradicional. O que será ratificado a partir de uma análise de $A$ segunda pátria (2015), do escritor paranaense Miguel Sanches Neto.

Em $A$ segunda pátria, Sanches Neto realiza um recontar da história do Brasil às avessas: Getúlio Vargas apoia Adolf Hitler, e a consequência disso é um estado em que a cassação aos diretos humanos, a violência e o autoritarismo dominam o sul do país. A partir disso, o Estado Novo, o Terceiro Reich, a personagem de Adolf Hitler, a perseguição aos negros (especialmente) no sul do país, o protagonista negro que vive um romance com uma alemã importante, são apenas alguns dos elementos que caracterizam o romance examinado.

Assim, é com o cenário brasileiro pré e durante a Segunda Guerra Mundial que a obra dialoga; entretanto, ao modificar um ponto fundamental do passado nacional e tornar o país um aliado do Terceiro Reich, a região sul brasileira passa a ser palco de ações pautadas no racismo, no antissemitismo e na eugenia, princípios básicos do nazismo. De tal modo, mostra como a violência, a privação de direitos e o controle autoritário afetariam, e 
afetam, a vida da população. Dessa forma, a narrativa apresenta um enquadramento histórico bem delimitado, mas não segue os princípios da história oficial, subverte-a, questionaa, mostrando um Brasil não oficial, mas temivelmente plausível.

Nessa empreitada, Sanches Neto reafirma o antigo e constante diálogo entre a ficção literária e o discurso histórico, mostrando como a produção literária contemporânea se articula intimamente ao discurso histórico e o problematiza. A narrativa enquadra-se, portanto, na acepção de Fleck (2017), como um romance histórico contemporâneo de mediação. Para o autor, esses romances são "produto da própria releitura contemporânea que o gênero romance histórico efetua de sua trajetória, num intenso processo de autorrenovação que faz do romance histórico a expressão mais apreciada do gênero romanesco ainda em nossos dias" (FLECK, 2017, p. 105). Apresentam como características principais o retorno da linearidade narrativa, geralmente ex-cêntrica; o esforço verossímil; e a linguagem fluída e coloquial.

À vista disso, sob a matriz metodológica da literatura comparada, o presente artigo realiza uma análise de $A$ segunda pátria (2015) com o objetivo de examinar como o seu discurso ficcional está atrelado ao discurso histórico, e como seus elementos ficcionais realizam um exame crítico da história dita oficial ao destacar as perspectivas daqueles que ficaram à margem do poder, relegados ao esquecimento. Além disso, pretende-se averiguar a consonância das teorias do romance histórico contemporâneo de mediação a um exemplar da ficção histórica contemporânea mais recente, a obra literária supracitada.

Para tanto, em busca de uma compreensão integral, optou-se por apresentar algumas considerações sobre a trajetória do romance histórico e, na sequência, partir para análise efetiva da narrativa híbrida de história e ficção A segunda pátria (2015), de Miguel Sanches Neto. 


\section{Escritas híbridas de história e ficção: considerações sobre a constante renovação}

\section{literária}

O romance histórico é um dos gêneros mais tradicionais e prolíficos da literatura ocidental, com narrativas tratando sobre fatos e personagens históricos desde a Antiguidade. Entretanto, seu início é apontado para as primeiras décadas do século XIX, durante o romantismo, com Walter Scott. A primeira publicação da narrativa híbrida denominada romance histórico, de acrodo com Lukács (2011), foi Waverley, em 1814, mas a sua popularização e estabilização como gênero se daria apenas em 1819, com o aclamado Ivanhoé. Com seus romances, Scott acaba por definir um modelo de romance histórico que obedece ao esquema traçado por Antonio Esteves (2010), que indica a instalação de dois princípios:

O primeiro deles é que a ação ocorre em um passado anterior ao presente do escritor, tendo como pano de fundo um abiente rigorosamente reconstruído, onde figuras históricas ajudam a fixar a época. Sobre esse pano de fundo situa-se uma trama fictícia, com personagens e fatos inventados pelo autor. Além disso, como segundo princípio, os romances de Scott e seus seguidores, bem ao gosto do romântico, costumam introduzir na trama ficcional um episódio amoroso geralmente problemático, cujo desenlace pode variar, ainda que, na maioria das vezes, termine na esfera do trágico. (ESTEVES, 2010, p. 31).

Scott ganha o status de precursor do romance histórico devido ao fato de que o que se produzia até então eram obras com representatividade social, mas na qual seus personagens não representavam sua época. Antes de Scott, os escritores apenas "captavam os traços essenciais de seu presente histórico com um realismo ousado e perspicaz, mas não veem historicamente aquilo que é específico de seu próprio tempo" (LUKÁCS, 2011, p. 34). Em outras palavras, os elementos históricos eram trazidos apenas como uma roupagem, sem sua fiel excentricidade e seu exato relato da época: "O que falta ao pretenso romance histórico anterior ao de Walter Scott é o elemento especificamente histórico: o fato de a particularidade dos homens ativos derivar da especificidade histórica de seu tempo" (LUKÁCS, 2011, p. 33). Desta forma, para Lukács (2011), o que importa no ro- 
mance histórico é demonstrar, de maneiras ficcionais, a existência, o ser-precisamente-assim das situações e das personagens históricas, desnudar as verdadeiras e mais intrínsecas relações entre o ser social e o seu contexto. Fica sendo, assim, tarefa do romancista histórico a figuração mais detalhada possível da interação concreta das circunstâncias históricas da época representada.

Lukács estabelece uma relação intrínseca entre a Revolução Francesa, a queda de Napoleão Bonaparte, e o decorrente surgimento do romance histórico durante o século XIX, com Walter Scott. Para o autor, a existência de momentos social e historicamente emblemáticos é como um fermento para esse tipo de produção literária, uma vez que "a continuação do romance histórico no sentido da historização da representação do presente, a continuação da história passada na figuração da história vivida, tem, no fim das contas, razões que não são estéticas, mas sócio-históricas" (LUKÁCS, 2011, p. 109). Desde então, o romance histórico vem ganhando diferentes desdobramentos, com autores de renome como Leon Tolstói, Onoré de Balzac, Goethe, Fiodor Dostoievski, dentre outros.

Essa produção literária ganhou novo fôlego a partir da segunda metade do século $\mathrm{XX}$, devido às novas perspectivas da história, difundidas a partir da Nova História e do Relativismo cultural. Ressalta-se que desde o início do século XX, há uma nítida transformação na forma de abordagem da história. Essas mudanças se iniciaram a partir do grupo de estudos conhecido como Escola dos Annales, desenvolvida em torno da revista Annales: économies, societés, civilisations, nos derradeiros anos da década de 1920. A formulação dessa nova perspectiva contou com personalidades como os historiadores Lucien Febvre e March Bloch, os quais viam a necessidade de uma renovação no trabalho com a história, e a relacionavam com outros campos da ciência, tais como a psicologia, a geografia e a sociologia. Por esse viés, a história passa a ser abordada em profunda interação com essas outras disciplinas, sobretudo com a economia e a sociologia.

Dessa multíplice abordagem da história surge um novo conceito: a nova história mais difundida na França como nouvelle histoire, disseminada pelas ideias do medievalista francês Jacques Le Goff. A escrita da nova história pode ser considerada como uma reação 
contra o paradigma tradicional traçado pela história rankeana ou positivista, aquele que percebia a história apenas como uma sucessão de acontecimentos, como um modelo de narrativa événementielle (BURKE, 1992). A partir de então, a nova história passa a se interessar por todas as esferas da atividade humana, chegando à noção de "história total", pois tudo, em todos os seus aspectos culturais, tem um passado e todo passado tem sua relevância. Apoiadas nessa vertente inovadora, surgem ramificações como a história regional, a história das mulheres, a história do corpo e também a micro-história. Ao remover o foco da organização sequencial de acontecimentos e mostrar as diferentes perspectivas de um fato, a história perde o seu caráter anteriormente imutável e passa a ser encarada como uma construção cultural, passível de alterações tanto no tempo quanto no espaço. Como consequência, o relativismo cultural da história torna-se tangível, ressaltando que, como revela a base filosófica da nova história, a realidade é social e culturalmente construída (BURKE, 1992, p. 9-10).

Nessa perspectiva, a história événementielle perde seu status de superioridade. Métodos e materiais antes não valorizados pela história tradicional passam a possuir maior relevância, não mais se atendo apenas aos documentos ditos oficiais, mas considerando também outras fontes de acesso ao passado, tal como as memórias e histórias orais, fotografias, diários e, especialmente, a literatura.

Por conseguinte, no âmbito artístico literário houve maior aproximação entre o discurso histórico e o discurso literário, uma vez que o primeiro perdeu sua categoria de verdade absoluta, passou a ser mais questionado e encarado como um discurso construído. Com tal condição, ocorreu uma nova onda de incertezas sobre a capacidade histórica de representar verbalmente a verdade histórica. Fator que assinalou como a literatura e a história possuem em comum um traço fundamental: ambas são formulações discursivas, portanto, permeadas pela organização subjetiva de seus locutores e possuidoras de infinitas ramificações discursivas (ESTEVES, 2010, p. 17). Nas palavras de Marilene Weinhardt (1994, p. 49), “todas as formas de resgate do passado são permeadas pela consciência de 
que a construção verbal não é o fato e não é ingênua”, todas são representações engendradas por seus produtores.

Logo, o romance histórico despontou como tipologia amplamente disseminada após esse período, e ganhou diferentes contornos a partir de então. Formas narrativas inovadoras ganham força, com maior autonomia, por meio de vigorosos recursos estilísticos, predominantemente, com viés crítico e engajado.

Cabe, aqui, assinalar que a característica da crítica social é crucial para a delimitação teórica do professor e teórico Gilmei Francisco Fleck (2017), que distingue a trajetória do romance histórico em cinco categorias e essas em duas posturas basilares: a postura acrítica, na qual estão os romances históricos clássicos e tradicionais; e a postura crítica, em que se enquadram o novo romance histórico latino-americano, a metaficção historiográfica e o romance histórico contemporâneo de mediação. Essa primeira postura, a acrítica, não faz parte do escopo principal desse estudo, motivo pelo qual a mesma não será mais bem examinada.

Das categorias elencadas por Fleck (2017), está o novo romance histórico latinoamericano. Essa tipologia foi amplamente debatida por Seymour Menton, em La nueva novela histórica de América Latina: 1949-1992 (1993), no qual o autor traça o surgimento do novo subgênero literário, que carrega consigo uma nova forma de abordar a história, além de algumas características recorrentes nas outras tipologias críticas, tais como: a releitura crítica da história, a legitimação de versões não oficiais (antes silenciadas); a multiplicidade de perspectivas para alcançar a diluição da unidade da verdade; maior aproximação com o leitor; a superposição de momentos históricos distintos; maior distanciamento da historiografia oficial; ampla gama de modalidades estilísticas expressivas, com recursos metaficcionais, intertextuais, paródicos, dialógicos, dentre outras características. Além disso, Esteves (2010, p. 36) também ressalta que o novo romance histórico latino-americano apresenta "uma polifonia de estilos e modalidades baseada, especialmente, na fragmentação dos signos de identidade nacionais, realizada a partir da desconstrução dos valores tradicionais”. 
Por essa característica, Fleck (2017) denomina essa tendência das escritas híbridas de história e ficção como uma tendência desconstrucionista e experimentalista (junto à metaficção historiográfica), nas quais há a intenção de ruptura, de estabelecer releituras desmistificadoras, em que as construções antes hegemônicas são plenamente desconstruídas.

Ressalta-se, ainda, que não há a necessidade de que uma obra contemple todas essas características para que a mesma seja caracterizada como um novo romance histórico latino-americano. Para Célia Fernandez Prieto (apud FLECK, 2017, p. 40) apenas duas características são definidoras dessa tipologia textual: 1- a distorção do material histórico na inclusão da diegese ficcional (que ocorre de três formas: histórias alternativas, apócrifas, contrafactíveis; procedimentos de hipertextualidades visíveis; e multiplicação de anacronismos); 2- a presença da metaficção como eixo formal e temático mais relevante.

Essa última característica apontada por Fernandez Prieto, no entanto, aproxima o novo romance histórico latino-americano de uma segunda categoria textual: a metaficção historiográfica, terminologia cunhada pela canadense Linda Hutcheon (1991). Para a autora, a metaficção-historiográfica se refere "àqueles romances famosos populares que, na literatura contemporânea ao mesmo tempo, são intensamente autorreflexivos e mesmo assim, de maneira paradoxal, também se apropriam de acontecimentos e personagens históricos" (HUTCHEON, 1991, p. 21). Em outras palavras, são romances ficcionais, metalinguísticos, que refletem sobre si mesmos, e que ao mesmo tempo se apropriam do discurso histórico oficial em suas elaborações; são distintivos também por serem fragmentados, subversivos, desconstrucionistas. Outra característica importante da metaficção historiográfica é a valorização e a problematização sobre o periférico. Na metaficção historiográfica, todas as vozes são ouvidas, o excêntrico (termo utilizado por Hutcheon), passa a ser centro, aquele que não tem voz - o marginal, o periférico - passa a possuir voz, todas as vozes são ouvidas e problematizadas: "A diferença sugere a multiplicidade, a heterogeneidade e a pluralidade, e não a oposição e a exclusão binárias" (HUTCHEON, 1991, p. 89).

Essas são estratégias narrativas que, assim como no novo romance histórico latinoamericano, visam um repensar crítico e problematizado sobre a historiografia, sobre os 
discursos aceitos como verdade, sobre os acontecimentos políticos e sociais, enfim, sobre o universo no qual estão inseridos.

De acordo com Fleck (2017, p. 79), a característica suprema de distinção entre o novo romance histórico latino-americano e a metaficção historiográfica é que essa última tem plena autoconsciência de sua condição discursiva, por isso se revela sempre voltada para si mesma. A característica denominada como autorreflexividade, metaficcionalidade, autotextualidade, autoconsciência, especularidade, todas utilizadas para se referir ao ato da arte fazer referência a si mesma é o fio condutor determinante na realização da metaficção historiográfica: "Neste tipo de obra, o que se deve observar é que a metaficcionalidade, seja ela discursiva ou narrativa, será a estratégia mais relevante e recorrente da composição romanesca", constituinte de uma dimensão junto ao todo da narrativa, na qual a retirada de seu caráter autorreflexivo ocasionaria um "total empobrecimento da narrativa e do próprio projeto estético-literário.” (FLECK, 2017, p. 93-4).

Às escritas mistas de história e ficção apresentadas, o novo romance histórico latino americano e a metaficção historiográfica, que podem ser descritas essencialmente como críticas e desconstrucionistas, se seguiu uma nova tendência de narrativa híbrida de história e ficção: o romance histórico contemporâneo de mediação. Essas produções ganharam maior representatividade na década de 1980, com caraterísticas estruturais e de linguagem mais simplificadas, que procuraram incorporar elementos do romance histórico tradicional amalgamados aos elementos mais desconstrucionistas para a elaboração de releituras críticas do passado.

O romance histórico contemporâneo de mediação mantém algumas características das modalidades anteriores, mais desconstrucionistas e experimentalistas. Entretanto, como aponta Fleck (2017), as alterações são bastante significativas, esses romances:

abandonam as superestruturas multiperspectivistas, as sobreposições temporais anacrônicas, os desconstrucionismos altamente paródicos e carnavalizados das releituras ficcionais anteriores. Elas adotam uma linearidade narrativa singela, com algumas analepses ou prolepses e um discurso crítico sobre o passado que privilegia uma 
linguagem próxima daquela cotidiana do leitor atual. Nelas, a construção da verossimilhança, em boa parte abandonada pelas escritas precedentes, volta a ser essencial. Contudo, não se configuram como escritas tradicionais do gênero, pois o passado é visto com criticidade, e as perspectivas dos marginalizados e excluídos são apresentadas, nessas narrativas, com tendências conciliadoras. (Fleck, 2017, p. 104).

Essa última característica apontada pelo autor é primordial no romance histórico de mediação. Essas narrativas não focam em personagens centrais, grandes heróis enaltecidos pela historiografia, mas se atêm às personagens históricas excêntricas, excluídas ou marginalizadas, com a finalidade de representar as perspectivas que foram negligenciadas pela historiografia oficial - aproximando-se, assim, da metaficção historiográfica na iniciativa de mostrar as múltiplas versões possíveis da história. Nesse ponto, essas obras literárias têm se caracterizado como um retorno crítico e questionador ao passado em que esses romances ganham novas perspectivas, representando o que Jim Sharpe (1992) denomina de a história vista de baixo, em outras palavras, a perspectiva dos perdedores, nos quais não são mais os personagens vitoriosos e centrais os focos de atenção, mas sim as opiniões e experiências de pessoas comuns. A esse movimento, Linda Hutcheon (1991, p. 89) chamará de descentralização através do excêntrico, ou seja, a refutação à centralidade da cultura por intermédio da valorização do local, do marginal, do periférico.

Essa estratégia, no romance histórico contemporâneo de mediação propiciará uma releitura ou revisão crítica de um passado de dominação e subjugação por meio de um "foco narrativo centrado em perspectivas deliberadamente excluídas dos registros históricos hegemônicos: mulheres, negros, nativos, europeus subalternos, degredados, fugitivos, portadores de necessidade especiais, rebeldes, anti-heróis etc.” (FLECK, 2017, p. 105).

Junto ao revisionismo crítico do passado - realizado pelo foco no excêntrico -, às características da linearidade narrativa e à busca pela verossimilhança, outro ponto de destaque dessa nova tendência é a simplicidade de linguagem, apresentada por meio de uma linguagem bastante coloquial, amena e fluida, sem os barroquismos e experimentalismos linguísticos frequentemente verificados nos novos romances históricos e na metaficção 
historiográfica. Ainda, a partir de Fleck (2017, p. 111), pode-se afirmar que também há ocorrências de recursos escriturais bakhtinianos, tais como a dialogia, a polifonia, a intertextualidade e a paródia, em detrimento de recursos mais marcadamente desconstrucionistas como a carnavalização, a ironia, as anacronias exacerbadas. De forma semelhante, os recursos metaficcionais também estão presentes no romance histórico contemporâneo de mediação, todavia, não desempenham papeis determinantes no sentido global da narrativa, tal como ocorre com a metaficção historiográfica.

São essas características, que se inserem entre as tipologias mais tradicionais e as mais desconstrucionistas do romance histórico, que determinam o romance histórico contemporâneo de mediação e aproximam essa produção literária mista de história e ficção ao leitor comum, pois utilizam-se da linearidade das ações históricas, optam por uma linguagem mais próxima da coloquial, com experimentalismos e desconstrucionismos mais comedidos, ancorados em uma perspectiva excêntrica que possibilita ao leitor a identificação de versões distintas (principalmente, diferentes da historiografia oficial) sobre os fatos do passado.

É com essa última modalidade de narrativas híbridas de história e ficção que o romance de Miguel Sanches Neto dialoga. A segunda pátria (2015) se caracteriza como um romance que apresenta o discurso histórico intimamente relacionado ao discurso ficcional, e que apresenta estratégias estético formais e narrativas que possibilitam a determinação da mesma como um romance histórico contemporâneo de mediação.

\section{A segunda pátria em busca da ressignificação crítica do passado brasileiro}

A única coisa que devemos à história é a tarefa de reescrevê-la.

Oscar Wilde

A segunda pátria (2015), de Miguel Sanches Neto, quita a dívida a que Oscar Wilde se refere de maneira exemplar. Antes dele, muitos outros romances já cumpriram essa tarefa das mais variadas formas, como ficou explícito na sessão anterior - e em muitas outras formas que não foram referenciadas. Essa tarefa de reescrever a história torna evidente um 
ponto crítico dos romances históricos: a intrínseca simbiose entre o discurso histórico e o discurso ficcional.

No romance em questão, ocorre uma reelaboração crítica do passado nacional às avessas. Situado na primeira metade do século XX brasileiro, $A$ segunda pátria recria o espaço do sul do país entre os anos de 1938 e 1941, e altera um ponto fundamental da historiografia nacional: nesse devaneio literário, o Brasil apoia ao Eixo - Alemanha, Itália e Japão -, e dá início a uma bárbara perseguição aos judeus, negros e indígenas.

Antes do desenvolvimento do texto literário, Sanches Neto apresenta um prólogo (sem título), no qual informa o teor do romance apresentado na sequência: "Este romance é uma variante ficcional da história do Brasil durante a Segunda Guerra Mundial. Embora alicerçado em questões latentes naquele período, ele nasceu das neuroses próprias de uma época de radicalismos e amplia temas e episódios que ainda hoje são tabus no Sul do país" (SANCHES NETO, 2015, p. 9). Assim, ao determinar o romance como uma recriação do passado brasileiro, alicerçada em problemáticas contemporâneas, o autor deixa as possibilidades interpretativas abertas, mostrando que o passado, mesmo em sua recriação ficcional, tem relações com o presente conturbado e carrega inúmeras marcas da história oficial. Essas marcas são apresentadas das mais variadas formas, como é afirmado ainda na mesma sessão: “[...] sendo esta obra o desenvolvimento narrativo de uma circunstância histórica que, pelo esforço e sofrimento de todos os envolvidos, não chegou a acontecer. Tudo não passa, portanto, de um pesadelo" (SANCHES NETO, 2015, p. 9).

Essas assertivas, por conseguinte, ressaltam uma problemática das narrativas híbridas de história e ficção: a distinção do histórico e do ficcional e o compromisso com a verdade histórica. Sobre o primeiro aspecto, a diferenciação entre os dois discursos, ressalta-se a opção por sua prescindibilidade. A obra em questão apresenta proeminência não por um ou outro aspecto isolado, mas sim pela reelaboração crítica, pelo diálogo profundo e profícuo entre as duas tipologias de discurso. Deste modo, não se pretende a separação e catalogação das duas tipologias discursivas, pautadas na exclusão binária, mas sim o 
exame atendo do produto desse diálogo. Ressalta-se também que, uma vez inserido no texto literário, tudo é ficcional.

Quanto ao compromisso com a verdade histórica, algumas reflexões mais elaboradas fazem-se necessárias: é imperativo considerar que a história e a literatura possuem sempre um mesmo referente, o real. Consoante a Pesavento (2006), ambas são narrativas que apresentam o real como referente, para confirmá-lo ou para negá-lo, constroem sobre ele uma nova versão ou o ultrapassam, recriam e explicam a vida. Dessa forma, são narrativas capazes de construir e modificar nosso imaginário, que se consolida como uma janela onde se recuperam as formas de ver, sentir e expressar o real dos tempos passados, como um sistema de valorização, identificação e classificação do real. Esse referente, o real, é apresentado de formas distintas pela história e pela literatura, por diferentes representações, carregadas de marcas de historicidade. Fato que lhes confere a propriedade básica que as diferencia: os historiadores trabalham com as marcas de historicidade e buscam a proximidade com o real acontecido, enquanto que os escritores de literatura não têm esse compromisso de veracidade.

De fato, o que distingue a história e a ficção é a busca ou o compromisso que a primeira possui com a verdade: enquanto a literatura aceita e se reconhece como ficção imaginativa, a história se pretende verdadeira: "A história evidentemente se distingue da ficção enquanto está obrigada a se apoiar na evidência do acontecimento, no espaço e no tempo reais do que descreve" (MINK, 1970, p. 44 apud LIMA, 2006, p. 156). Enquanto o historiador busca a verdade histórica, o ficcionista pode se eximir desse compromisso. A literatura suspende essa busca ou obrigação, mas nem por isso deixa de carregar a sua veracidade: "A verdade da história sempre mantém um lado escuro, não indagado. A ficção, suspendendo a indagação da verdade, se isenta de mentir. Mas não suspende sua indagação da verdade" (LIMA, 2006, p. 156). Enquanto a verdade mantém um impasse no discurso histórico, na ficção ela perde essa condição, pois enquanto na história a mimeses recebe um papel secundário e a ambição pela verdade se torna essencial, o poeta ou romancista abandona essa pretensão de veracidade. 
Nos romances históricos de postura crítica, o objetivo essencial do diálogo com a história é demostrar que não existe uma verdade única sobre o passado, mas sim diferentes verdades constituídas em discursos ideológicos pautados em elementos condicionantes. Em consonância com o que já foi demostrado sobre o relativismo cultural, a partir de pensadores como Peter Burke (1992) e Hayden White (2001), ao afirmarem que toda representação do passado, histórica ou literária, tem implicações ideológicas específicas. Dessa forma, “A distinção mais antiga entre ficção e história, na qual a ficção é concebida como a representação do imaginável e a história como a representação do verdadeiro, deve dar lugar ao reconhecimento de que só podemos conhecer o real comparando-o ou equiparando-o ao imaginável' (WHITE, 2001, p. 115, grifos do autor).

Com isso em vista, em A Segunda Pátria (2015) conhecemos o engenheiro civil Adolpho Trajano Ventura, negro estudado que perde progressivamente sua liberdade, o emprego, a casa, seu filho mestiço e qualquer outro direito depois do pacto nazista. Ironicamente, o nome do protagonista lhe foi dado em homenagem ao filho do chefe de seu pai, morto durante a Primeira Grande Guerra. Esse chefe lhe garantiu seu status social, pois lhe ofereceu instrução e os primeiros estudos, o que o incentivou aos estudos posteriores no Rio de Janeiro.

Adolpho aprendeu a dominar o idioma alemão na casa dos patrões de seu pai, seus escritores preferidos eram alemães, frequentara a Neue Deutsche Schule, escola que recebia dinheiro da Alemanha, sonhava na língua estrangeira e até mesmo se sentia mais identificado ao povo alemão do que ao brasileiro:

Herr Ventura se sentira sempre isolado no Rio, e essa solidão só não era maior porque conseguia encontrar um ou outro descendente de alemão em viagem ou morando na capital federal. [...] Os demais negros com quem convivia o tratavam desdenhosamente como mulato, embora fosse tão puro quanto eles. Talvez por seus hábitos estrangeiros. Nunca amou o Rio e permanecia ali porque precisava concluir a faculdade. Nos momentos de maior otimismo, imaginavase morando na Alemanha, mesmo sabendo que só poderia conseguir, em termos de trabalho, emprego nas áreas de colonização 
alemã no Sul do Brasil. (SANCHES NETO, 2015, p. 14-5, grifo do autor)

Todas as características subjetivas do protagonista são construídas em consonância ou em relação aos parâmetros alemães, seus costumes, leituras, apreços amorosos. Após as intervenções do Partido Nazista do Brasil, a privação do direito a esses aspectos caracteriza uma perda gradual da identidade inicial do autor, talvez o termo mais adequado seja: a usurpação lenta e definitiva da identidade de Adolpho - tal como sucedeu com o sem emprego, sua biblioteca, sua casa, sua liberdade. A não identificação com sua realidade é patente o excerto que se reproduz a seguir, no qual também se reafirma o apreço ao idioma germânico:

O idioma se tornara um recurso para a leitura e tudo o que ele desejava, ao identificar esse isolamento, era voltar para casa, abrir um livro e se perder em obras que ignoravam a sua cor - uma cor que, antes apenas malvista, acabara uma ofensa. Ler como uma forma de encontrar-se com sua alma era algo que fizera em todo o tempo de estudante, só que por outros motivos. No Rio, ele lia em alemão para voltar ao local em que se criara. Agora, para fugir dele. (SANCHES NETO, 2015, p. 24)

Essa transformação é acentuada quando o engenheiro é levado à Fazenda Vita Nova, em que o estado de privação e degradação é levado ao extremo, sem nenhuma condição de higiene, alimentação precária e regime de trabalho escravo. Nesse mesmo local, o protagonista recebe uma nova identificação, dessa vez numérica: “Outro homem, com ferros quentes, inscreveu o seu número, de acordo com a certidão emitida pelo Partido Nazista. Era o $n^{\circ}$ 6.052. Tivera um nome durante a infância. Depois recebera outro. E agora era apenas esses dígitos" (SANCHES NETO, 2015, p. 62). Percebe-se, assim, que além do nível subjetivo, essa perda de identidade também ocorre no uso de seu nome na narrativa. No início do romance o protagonista é chamado pelos personagens secundários e pelo narrador em terceira pessoa, predominantemente, de Adolpho e no transcorrer da narrativa ele passa a ser denominado apenas de Trajano, o nome que seus pais haviam lhe dado antes 
do batismo. Essa alteração de nomenclatura está intimamente relacionada a perda de direitos sofrida pelos negros e demais grupos marginalizados, sendo representativa não apenas ao personagem protagonista, mas a todo uma comunidade de indivíduos.

No transcorrer da narrativa, o autor tece um enredo em que figuras e fatos ficcionais são amalgamados à história oficial na missão de reelaborar criticamente o passado nacional. Para isso, figuras históricas como o próprio Adolf Hitler, Getúlio Vargas, Gregório Fortunato e Oswaldo Aranha, dentre outras, são ficcionalizadas e inseridas em posições e situações não oficiais. Ao serem realizadas, essas inserções ficcionais colaboram com a revisão crítica do passado histórico, fazendo com que a verdade sobre o passado histórico seja questionada.

Além disso, essas inserções são consoantes àquilo que Vargas Llosa afirma sobre a capacidade representativa da literatura ao afirmar que a mesma é capaz de dizer a verdade por meio do engodo, pois os romances não podem fazer outra coisa senão mentir, mas nesse ato expressam uma verdade peculiar, encoberta: "las novelas mienten - no pueden bacer otra cosa - pero esa es sólo una parte de la bistoria. La otra es que, mintiendo, expresan una curiosa verdad, que sólo puede expresarse encubierta, disfrazada de lo que no es" (VARGAS LLOSA, 2007, p. 16). Desse modo, os elementos "autênticos" trazidos pela História são diferentes dos retratados pela literatura, pois as "mentiras" que a literatura conta trazem verdades impossíveis de serem contadas pelo historiador ou de outra forma, pois essas são veladas, deturpadas ou aumentadas, encobertas por uma espessa teia estilística ou pelo manto da fantasia, pois como assegura o autor: nos enganos da literatura não há engano nenhum.

Essa habilidade das escritas híbridas de história e ficção, especialmente do romance histórico contemporâneo de mediação, de refletir criticamente sobre o passado histórico é ampliado devido à característica essencial dessa tipologia narrativa: ao realizar a releitura do passado, as mesmas abrem espaço à perspectiva dos marginalizados, dão voz aos excluídos socialmente: 
Essas narrativas híbridas de história e ficção atuais não se fixam, como ocorre com o novo romance histórico, em grandes heróis mitificados pelo discurso historiográfico e na releitura de suas ações com o intuito de romper imagens cristalizadas e mitificadas destes. Antes da desconstrução de heróis consagrados e suas ações, elas buscam por personagens históricas periféricas, marginalizadas ou excluídas - ou metonímias destas -, a fim de representar perspectivas silenciadas e negligenciadas pela historiografia. São releituras críticas do passado, com personagens protagônicas ex-cêntricas, como ocorre várias vezes na metaficção historiográfica, contudo, sem o sumário intendo da desconstrução radical que orienta a produção crítica precedente. (FLECK, 2017, p. 105).

Em A segunda Pátria, a personagem protagonista é metonímica, representa as diversas categorias oprimidas e marginalizadas, especialmente a do negro. Por isso, diversas personagens da história oficial são inseridas no enredo ficcional, mas não como personagens centrais, e sim como figuras secundárias que contribuem para a construção da verossimilhança. Ao realizar essa tarefa, dá voz àqueles que tiveram suas vozes silenciadas pela história hegemônica, aos excluídos, massacrados e segregados socialmente. A perspectiva do negro perseguido, daquele que sofreu preconceito e violência é colocada em evidência. $\mathrm{O}$ excerto a seguir é representativo de como ocorre a inserção dessa perspectiva excêntrica na narrativa, bem como a inclusão das figuras históricas na mesma:

Ele estava informado dos muitos judeus que Getúlio estava mandando de volta para a Alemanha, cumprindo o acordo com o Terceiro Reich. Quando Gregório soube da visita de Hitler a Porto Alegre, e estando ele ainda a serviço dos Vargas em São Borja, sentiuse preterido por não ser chamado para acompanhar o presidente. Hoje, achava uma sorte não ter ido e via que não poderia ter conhecido o líder germânico. Era um negro, palavra que tinha assumido uma significação mais forte nos últimos anos. Nem todos no Sul eram alemães; mas a maioria sonhava com um Brasil que não existia. (SANCHES NETO, 2015, p. 282)

O trecho acima representa a perspectiva de Gregório de Fortunato, negro que, factualmente, foi o chefe de segurança de Getúlio Vargas. No enredo ficcional, Gregório Fortunato é a figura que assassina por sufocamento o então presidente, a mando do então 
Ministro de Relações Exteriores, Oswaldo Aranha. Oferece, portanto, uma nova versão às muitas especulações sobre o suicídio de Vargas, que também permanece sem solução: “Oswaldo Aranha, tal como fizera no Rio Grande do Sul, durante a Revolução de 30, assumiu o lugar de Vargas e fez de Gregório o chefe de sua guarda pessoal. Sob suspeita de assassinato, mas sem nenhuma prova, o enterro de Getúlio aconteceu no início da guerra civil" (SANCHES NETO, 2015, p. 288).

Com o desenrolar da narrativa, desvenda-se uma história de amor não convencional: Adolpho (ou Trajano, como também será chamado) vive um romance com Hertha Sheiffer, branca, com descendência alemã, mãe de seu filho. Hertha era uma jovem com experiência sensual, dona de si e de eu corpo; quando jovem, era relacionada aos ensinos nazistas, mas que abandona esses ideais pela liberdade a que era destinada. A partir da perspectiva dessa personagem, e de outros que aparecem com menor espaço, o narrador em terceira pessoa - onisciente e onipresente -, tece um enredo em que elementos da história oficial são fundamentais para o questionamento e para a crítica realizada à verdade historiográfica. A seguir, a inclusão da Juventude Teuto-Brasileira, a referência ao Partido Nazista e seus ideais faz um convite a refletir criticamente sobre as verdades da história hegemônica:

Ela conhecia bem os jovens que a vigiavam. Vira muitos deles na Alemanha, na única viagem à terra de seus antepassados, em 1935. Eram fanáticos do Partido Nazista e se comportavam como se fossem os santos de uma religião — o nacionalismo ariano - , subordinando-se à pátria. [...], ela participara da Juventude Teuto-Brasileira, e como outros sonhara com uma Alemanha que transpusesse o oceano e incorporasse as colônias. Nos encontros com aqueles jovens, aprendera a cultuar o país de seus pais: gedenke dass $d u$ ein Deutscher bist. Jamais se esquecera de que era uma alemã, e nas palestras aprendera a ter orgulho disso. (SANCHES NETO, 2015 p. 109)

Da mesma maneira, também ocorre a inserção de diversas referências a personagens históricas e literárias, além da inclusão de fatos e elementos da historiografia tradicional, como a já referida existência da Juventude Teuto-Brasileira, as referências às ações do Partido Nazista Brasileiro, as alusões às lutas anteriores na Alemanha, a participação do Partido 
Nacional-Socialista dos Trabalhadores Alemães, as ações da Ku Klux Klan, dentre outros. Essas inclusões corroboram, sobretudo, para a conferência de verossimilhança ao romance, que é um dos aspectos mais relevantes nessa tipologia narrativa, como bem aponta Fleck ao definir o romance histórico contemporâneo de mediação:

Tão importante como é para o novo romance histórico e a metaficção historiográfica revelar que tanto história como ficção são discurso e que não há "verdade" sobre o passado, mas múltiplas "possibilidades” de percepção, para essa modalidade, é a construção de verossimilhança que dá credibilidade a outras perspectivas do passado ao longo do relato. (FLECK, 2017, p. 105, grifos do autor)

O que confirma também a utilização de referentes geográficos bem definidos (cidades, ruas, rios) e a caracterização detalhada do tempo e espaço. Outro ponto que corrobora para a apresentação verossímil da narrativa é a aparição, em raras ocasiões, de transcrições informativas, na forma de noticiários de rádios, representando as notícias que eram repassadas à população pelo único meio de informação acessível à época:

Alô, brasileiros. Uma onda de pequenas mentiras está correndo o país e é obrigação da Rádio Nacional do Rio de Janeiro alertar os seus ouvintes. A última acusação infundada que o presidente do Brasil, o senhor Getúlio Dornelles V argas, recebe é a de que o Estado Novo persegue os negros do Sul. Essa bobagem partiu do comunista Abdias do Nascimento, que se encontra detido na penitenciária do Carandiru por manifestações políticas contrárias à ordem nacional, com o pretexto de defender os de sua cor. Abdias é um grande arruaceiro e, condenado em 1937 pelo Tribunal de Segurança Nacional, esteve preso na Casa de Correç̧ão.

O presidente do Brasil informa que os negros do Sul, sua região de origem, estão sendo muito bem tratados por instituições de ensino e de caridade, que os retiram das ruas e da vida viciosa, levando-os a atividades saudáveis. O que os difamadores como o senhor Abdias chamam de perseguição aos negros é um grande projeto de educação pelo trabalho que se inicia no Sul e deve chegar a todo o país. Ouvindo a Rádio Nacional, prefixo PRE-8, o senhor, cidadão que trabalha para o progresso do Brasil, se mantém informado. Não deixe de denunciar os baderneiros. (SANCHES NETO, 2015, p. 265, grifo do autor)

Ainda, são nessas inserções que se verificam episódios polifônicos mais explícitos no romance. No restante do texto, há a presença de um narrador que conduz toda a estória. 
Esse narrador em terceira pessoa é onisciente e onipresente, conhece os sentimentos e as atitudes de todos as personagens, portanto, carrega características diversas e contraditórias. Outrossim, é consciente de sua posição narrativa, como deixa vislumbrar em esporádicas situações em que dialoga com o leitor, tal como em: “[...], talvez alguns até soubessem de sua ligação com os nazistas, só que viam o seu sofrimento, acompanhavam o seu cansaço, e quem trabalhava tanto assim, quem não tinha o menor orgulho, bem, só podia ser correto. Esqueçamos, pois, que no passado ele se sonhou outro" (SANCHES NETO, 2015, p. 71). Fato que torna a obra, por conseguinte, consciente de sua posição de discurso literário.

Além do diálogo perscrutador com o passado, Fleck (2017, p. 109-111) estabelece outros seis aspectos que são basilares ao romance histórico contemporâneo de mediação, são eles:

1) uma releitura crítica e verossímil do passado, como já foi amplamente discutido e demostrado nessa sessão, essa é a característica considerada essencial ao romance ora cotejado.

2) Apresentação de narrativa de forma linear: $A$ segunda pátria é dividida em quatro partes, cada uma delas tem um tempo bem definido, inclusive com o ano: Neger, 1940; Wolfsschlucht, 1938; A teoria do lobo, 1941; e Kanibalen, 1941. Nessas quatro partes o leitor é apresentado a diversos capítulos, que avançam e retornam o tempo da narrativa, especialmente por meio de memórias apresentadas por seus personagens. No entanto, esse recurso não chega a realizar uma ruptura radical da linearidade narrativa (como fazem as tipologias mais desconstrucionistas dos romances históricos), o que faz com que o texto seja caracterizado como linear, apresentando apenas algumas analepses e prolepses, que colaboram no entendimento e desenvolvimento da narrativa.

3) um foco narrativo centralizado e excêntrico: como também já foi demonstrado, o foco narrativo é em terceira pessoa, esse narrador, no entanto, acompanha diferentes personagens: Adolpho Trajano Ventura; seus pais, João e Erendina Ventura; Hertha Sheiffer; Gregório Fortunato e Julius Meister, soldado do partido Nazista do Brasil. Com exceção do soldado, todos os demais personagens podem ser classificados como excêntricos, 
pois não constituem personalidades centrais e tiveram suas perspectivas silenciadas pela historiografia tradicional. Essa constância em terceira pessoa é rompida apenas nos três episódios em que são apresentados trechos de notícias.

4) emprego de linguagem, fluída e coloquial: como pode ser percebido ao longo dessa análise, a linguagem de $A$ segunda pátria é bastante acessível, suas estratégias narrativas tornam o texto bastante fluído, com desenvolvimento narrativo rápido, colaborado pela linguagem coloquial e a ausência de estratégias linguísticas e literárias experimentalistas e desconstrucionistas.

5) emprego de estratégias escriturais bakthinianas: a paródia pode ser percebida como a principal característica do romance, juntamente à dialogia e as intertextualidades, tanto com outras obras literárias como com o discurso histórico tradicional. E a última delas,

6) e a presença de recursos metaficcionais: as quais são as mais raras das demais propriedades elencadas por Fleck (2017), presente apenas nos momentos em que as personagens fazem referências a outros textos e autores; assim como ocorre na passagem em que Hertha relembra as histórias contadas durante sua estadia na Alemanha, e depois percebe que a mesma era uma alusão a um romance que lera:

Ele resumiu para o grupo a história de $O$ chamado selvagem, de Jack London. Depois Hertha foi ler esse livro de aventura, a história de um busky chamado Buck que seguia para o Alasca junto com os garimpeiros e, passando por muita provação num contato com a vida bruta, se fazia líder dos lobos. O final do livro era arrepiante. Buck comandava a alcateia de lobos selvagens, assustando os moradores. Uivava, entoando a canção do mundo rejuvenescido.

Neubert explicava o desfecho.

- Rejuvenescer é voltar aos valores da selva, seguindo o seu chamado. E citava o poema "Atavismo", de John Myers O'Hara, que Jack London usara como epígrafe (SANCHES NETO, 2015, p. 223, grifos do autor).

Todas essas propriedades, com maior ou menor frequência, fazem de $A$ segunda pátria um romance histórico contemporâneo de mediação, conforme concebido por Fleck 
(2017), no qual a ficção dialoga com o discurso histórico e o recria. Assim, A segunda pátria recria um espaço que não é apresentado nos livros de história tradicionais, em livro de história algum. Abre espaço, mesmo que ficcionalmente, para uma perspectiva possível, verossímil, condizente com o histórico de exploração e opressão vivido por inúmeros brasileiros. De fato, tal como afirma Walter Benjamin (2012, p. 243), "articular historicamente o passado não significa conhecê-lo 'tal como ele foi'. Significa apropriar-se de uma recordação, como ela relampeja no momento de um perigo". Trata-se, portanto, "de fixar uma imagem do passado da maneira como ela se apresenta inesperadamente ao sujeito histórico, no momento do perigo. O perigo ameaça tanto a existência da tradição como os que a recebem. Ele é um e o mesmo para ambos: entregar-se às classes dominantes, como um instrumento".

Por fim, $A$ segunda pátria oferece uma perspectiva que, como já dizia o autor, não passa de um terrível pesadelo, mas esse pesadelo é terrivelmente possível em épocas de radicalismos. Além disso, ainda de acordo com Sanches Neto, esse também é um dos papéis da literatura: "fazer com que vivamos acordados os piores sonhos da humanidade" (SANCHES NETO, 2015, p. 9).

\section{À guisa de conclusão: considerações sobre o porvir}

De forma bastante sucinta, buscou-se realizar, em um primeiro momento, uma abordagem teórica sobre as tipologias literárias que dialogam intrinsecamente com o discurso histórico, denominadas como escritas híbridas de história e ficção, abrangendo apenas aquelas se relacionam criticamente com a história hegemônica. Nesse, destacaram-se as três tipologias críticas de narrativas híbridas: o novo romance histórico latino americano, a metaficção historiográfica e, por fim, o romance histórico contemporâneo de mediação, tipologia e teoria que alicerça a análise literária apresentada.

Na sequência, apresenta-se um exame crítico de $A$ segunda pátria (2015), do escritor e ensaísta paranaense Miguel Sanches Neto, o qual configura-se como um romance histó- 
rico contemporâneo de mediação, denominação dada por Fleck (2017). Essa, uma modalidade de narrativa híbrida recentemente delimitada e visivelmente fértil, é caracterizada especialmente pelo retorno à linearidade narrativa, pela busca da verossimilhança e pelo emprego de linguagem predominantemente coloquial (FLECK, 2017, p. 107), elementos que foram abandonados pelas produções híbridas precedentes.

Outras duas particularidades imprescindíveis de $A$ segunda pátria é a releitura crítica do passado por meio de um foco narrativo que permite a perspectiva do excêntrico, ou seja, permite o acesso à história vista de baixo, como designa Jim Sharpe (1992), à história contada pelo perdedor, por aquele que teve sua voz silenciada e oprimida pela história tradicional. Esse aspecto é aqui percebido como o mais importante atributo dessa tipologia textual: viabilizar a ruptura com a opressão, os preconceitos, os silenciamentos e os abusos herdados por um passado de exploração e aniquilação cultural. Essa problematização ganha maior relevância em países que possuem um histórico de conflitos culturais e de lutas por riquezas, como é o caso dos países formadores da América Latina, em que, devido ao histórico de colonização europeia, a versão dos vencedores sempre foi predominante.

$\mathrm{Na}$ trajetória de $A$ segunda pátria, ao mesmo tempo em que dá vida a uma versão ficcionalizada da história, Miguel Sanches Neto reafirma o diálogo entre a ficção literária e o discurso histórico. Mostra, assim, como a produção literária contemporânea se articula intimamente com o discurso histórico oficial, problematiza profundamente a representação do passado e questiona as verdades da história hegemônica.

Dessa forma, ao apresentar uma história alternativa e extrema para um momento tão conturbado como o período das Grandes Guerras, A segunda pátria é exemplar da capacidade representativa a que Mario Vargas Llosa (2005) se referia: por meio da mentira, do engodo, a ficção literária é capaz de exprimir as mais duras e temíveis verdades. Nas palavras de Sanches Neto, os piores sonhos da humanidade.

Face a essa problemática, alçada por Sanches Neto já nas primeiras páginas de seu romance, considera-se pertinente uma aproximação de $A$ segunda pátria à alegoria do Anjo da História, apresentado por Walter Benjamim (2012) a partir da pintura de Paul Klee, 
chamada Angelus Novus, de 1920. Esse anjo, em analogia ao romance aqui analisado, apresenta-se com os pés no presente, mas está voltado para trás, ou seja, para o passado (um amontoado de ruínas formando uma única catástrofe), e uma tempestade o impele para a frente, para o futuro (também catastrófico), que tanto o atormenta. É na busca de evitar esses pesadelos, que se deve ouvir o apelo do passado, tal como $A$ segunda pátria demanda.

\section{FROM REVISITING TO RECREATING NATIONAL HISTORY: A POSSIBLE READING OF A SEGUNDA PÁTRIA, BY MIGUEL SANCHES NETO}

ABSTRACT: The present text is configured as an analysis of the novel $A$ segunda patria (2015), by the writer and essayist Miguel Saches Neto. By a comparative perspective, it examines the relations between historical discourse and literary discourse, as well as the different critical typologies of hybrid narratives of history and fiction, and approaches the novel to the so-called contemporary historical novel of mediation, designed by Fleck (2017). Thus, it focuses on the essentials aspects of this novelistic narrative: a critical and verisimilar re-elaboration of the past, carried out through an ex-centric narrative focus, which enables a presentation of a previously marginalized prospects, relegated to oblivion. In this way, it presents how the contemporary literary production deeply articulates with the historical discourse, problematizes its representation and questions the truths of hegemonic history.

KEYWORDS: Contemporary historical novel of mediation; Fiction; History; Miguel Sanches Neto.

\section{REFERÊNCIAS}

BENJAMIN, Walter. Magia e técnica, arte e política: ensaios sobre literatura e história da cultura. Trad. de Sérgio Paulo Rouanet. 8 ed. São Paulo: Brasiliense, 2012 (Obras Escolhidas vol.1).

BURKE, Peter (Org.). A escrita da história: novas perspectivas. Trad. Magda Lopes. São Paulo: Editora Unesp, 1992.

ESTEVES, Antonio. O romance histórico brasileiro contemporâneo (1975-2000). São Paulo: Ed. UNESP, 2010.

FLECK, Gilmei Francisco. O romance histórico contemporâneo de mediação: entre a tradição e o desconstrucionismo - releituras críticas da história pela ficção. Curitiba: CRV, 2017.

HUTCHEON, Linda. Poética do Pós-Modernismo: História, Teoria, Ficção. Trad. de Ricardo Cruz. Rio de Janeiro: Imago, 1991. 
LIMA. Luiz Costa. História. Fiçãa. Literatura. São Paulo: Companhia das Letras, 2006.

LUKÁCS, György. O romance histórico. Trad. Rubens Enderle. São Paulo: Boitempo, 2011.

NETO, Miguel Sanches. A segunda pátria. 1. ed. Rio de Janeiro: Intrínseca, 2015.

PESAVENTO, Sandra Jatahy. "História \& literatura: uma velha-nova história". Nuevo Mundo, Mundos Nuevos. Débats, 2006. Disponível em: http://nuevomundo.revues.org/1560. Acesso em 29 de maio de 2018.

SHARPE, Jim. "A história vista de baixo". In: BURKE, Peter (org.). A escrita da história: novas perspectivas. Trad. de Magda Lopes. São Paulo: Editora Unesp, 1992. p. 39-62.

VARGAS LLOSA, Mario. La verdad de las mentiras. Buenos Aires: Alfaguara, 2005.

WEINHARDT, Marilene. "Considerações sobre o romance histórico". Revista de Letras. Curitiba: UFPR, n. 43, p. 49-59, 1994.

WHITE, Hayden. Trópicos do discurso: ensaios sobre a crítica da cultura. Trad. Alípio Correia de Franca Neto. 2. ed. São Paulo: Edusp, 2001.

Recebido em: 31/05/2018.

Aprovado em: 16/07/2018. 